\title{
REQUIREMENTS AS OPERATIONAL METRICS? - CASE: FINNISH DEFENSE FORCES
}

\author{
Markus Häyhtiö \\ National Defence University Finland, Defence Acquisition, Finland \\ Corresponding author: \\ Markus Häyhtiö \\ National Defence University Finland, Defence Acquisition \\ Helsinki, Finland \\ phone: +358-(0)45-1200304 \\ e-mail: markus.hayhtio@kolumbus.fi
}

Received: 1 June 2016

Accepted: 28 August 2016

\begin{abstract}
The purpose of this paper is to study how requirements management could be utilized in connection to a service performance measurement system. Public private partnership (PPP) in Finnish Defence Forces' (FDF) catering operations is studied as a case example.

There are two research questions, which are studied: Firstly, do catering operations create KPI's, which enable inter- functional co-operation and service development? Secondly, do these KPIs support both efficiency and effectiveness of PPP catering operations?

Evidence from the previous studies on the subject indicates that there should be a single "power-by-the-hour" metrics unit, which enables a transparent follow-up of the performancebased operations. This research highlights requirements value in creation of economic efficiency and effectiveness from the end-user point-of view and reciprocal value creation between inter-functional service systems. This research's results show that focus on portion control can produce information, which enhances inter-functional co-operation between PPP stakeholders.
\end{abstract}

KEYWORDS

requirements management, performance based logistics, catering operations, public private partnership.

\section{Introduction}

Role of privately operated, previously public functions have increased their importance in Europe during the last decade. Over the past 25 years there have been more than 1300 public private partnership (PPP) contracts in EU worth more than 5 million [1]. Purpose of the PPP is to reduce costs, enhance efficiency and transfer operational risk in the operations previously run by public entity by transferring these functions to a privately run entity/company [2]. PPP is a widely studied subject but still questions referring to responsibilities, overall roles of these profit generating enterprises and most of all management of the relationship causes debate. This debate reflects the ideological background of the debate participants and easily takes the focus out of the possible, proven benefits of the PPP [3]. This research highlights requirements value in creation of economic efficiency and effectiveness from the end-user pointof view and reciprocal value creation between interfunctional service systems.

In this paper there are two research questions, which are studied: Firstly, do catering operations create KPI's, which enable inter- functional cooperation and service development? Secondly, do these KPIs support both efficiency and effectiveness of PPP catering operations?

The purpose of this paper is to study how requirements management could be utilized in connection to a service performance measurement system. Two variables representing financial requirements and customer requirements have been chosen: financial value per dish or ingredient and energy value per dish or ingredient.

Concept of Key Performance Indicators (KPIs) was introduced by two Harvard professor Robert Kaplan and David Norton already 1992 [4]. Purpose of 
the KPIs is to measure non-financial metrics and add them to the more traditional financial metrics while assessing company's results. A decision to use KPIs in the service operations' development is a quite natural one. Having said that, there are service specific features, which must be taken in to consideration.

According to [5], services are produced and consumed simultaneously. Therefore there is a real risk that predefined KPIs do not reflect the actual production/consumption process. KPIs in the form of requirements increase transparency and offer an unambiguous form of communications between stakeholders. More precise, but simple customer centric outcome metrics enable development of operations without compromising each stakeholders predetermined goals. This demands a structured mechanism to gather, collect and analyse these goals and use of requirements management can improve these processes. Further more, well-defined requirements contribute to the service operations management development relevant disciplines, such as strategic management, organizational behaviour and service marketing.

PPP requires a management model or an approach, which combines service production, transparent metrics in a form of requirements and interfunctional process management. Performance based logistics is a system, which focuses on the outcome of the service processes which value is always defined by the beneficiary of the service product $[6,7]$. Outcome of the service processes should be in the form of pre-defined requirements. Results from the earlier researches indicate that requirements management enhances the overall effectiveness. Goal oriented requirements management steers sub-system development and management and reduces individual subsystem development at the cost of the common goal $[8,9]$. Management model is scalable to other industries than one research here, but there must be a high contingent operations' awareness. Development requirements must be formed to suit existing operational production environment and process beneficiaries.

\section{Public Private Partnership}

A Public private partnership exists when a public authority is transferred to private sector. This authority transfer fulfils private and public outcomes previously offered by a public entity [10]. In PPP a long-term goal is to increase public service efficiency by using private service provider [1]. In PPP the whole life-cycle of the contract is linked to the several metrics such as quality of the service delivered and level of the service delivered [11]. These metrics should enable constant follow-up and development in a way, which can help to negotiate performance based contracts. Metrics should be transparent and both risks and rewards should be shared following the basic principles of the PPP, illustrated in the Table 1.

Table 1

Public Private Partnership.

\begin{tabular}{l|l}
\hline Wang, 2009, & "...partnerships, involves a far \\
p. $779[12]$ & $\begin{array}{l}\text { more intensive interaction (or syn- } \\
\text { ergy), which requires strategic col- } \\
\text { laboration and inter-tangled ac- } \\
\text { tion between the public and pri- } \\
\text { vate parties from the very begin- } \\
\text { ning of a project. ln a partnership, } \\
\text { two parties conduct joint decision } \\
\text { making and specify the problem, } \\
\text { solution, and product in the joint } \\
\text { process." }\end{array}$ \\
\hline Demirag et al., & "...involves the public and private \\
sectors sharing the risks and re- \\
wards on clearly defined projects \\
financed by the private sector."
\end{tabular}

As reference [11] research's results showed, diversity in PPP has increased during the past years. Part of this change is also witnessed in Finland. A public entity, Finnish Defence Forces (FDF) has formed strategic PPPs with several private operators [13]. One of these strategic partners is Leijona Catering, which runs all the catering operations on behalf of the FDF.

In a PPP all financial rewards should be tied to any contract extension or renewal to contractor's achievement [14]. Controlling and monitoring process of the partnership should respect both parties and measures should be as neutral as possible. Efficiency should be measured in a way that the principle described by Doerr et al. (2005, p. 167) is met:

"Are purchasers sufficiently rational and careful, and the quality of the service sufficiently definable and measurable, that effective, informed consumer sovereignty can be exercised?" [15].

One should bear in mind that in their research by [16] bring to a readers attention a fact that benefits of privatization are not clear-cut.

\section{Performance based logistics (PBL) - a service management model in a military context}

Service as a research discipline is very fragmented and development of services requires a multidiscipline approach [9]. One of these approaches (in 
military context) is PBL, a combination of several logistics function [17]. Each of these logistics functions/services and the whole service system requires a measurable outcome, a KPI. These intra-entity and inter-entity KPIs form the service system measurement network. Therefore management and development of a PBL system requires a goal given in the form of requirements and embedded network, as work by [4] and [18] shows.

In performance-based logistics (PBL) responsibility of the product/service system management is on a supplier of the system, unlike in the traditional enduser - supplier relationship [19]. In PBL according to Berkowitz et al. (2003, p. 5):

"...contractual mechanisms will include longterm relationships and appropriately structured incentives with service providers..., to support the end user's (warfighter's) objectives." [20].

In PBL a customer buys predetermined outcomes. These outcomes are dependent on and simultaneously vulnerable to outcomes of sub-systems. This interdependency is similar to the service systems and demands close co-operation among the whole supply chain [21]. A widely used example of the PBL is the case of Rolls-Royce. Rolls-Royce built a contract model in which a fixed price per flying hour covered all the maintenance and spare parts. This made it possible to predict the cost of the service and reduced the uncertainty of the purchaser [9].

Efficient PBL operations demand a completely transparent set of simple, realistic, consistent and easily quantifiable metrics [6]. They should support all the operations and take into account all the stakeholder groups participating to the service production [3]. Therefore a traditional customer centric service development perspective is not fully valid notwithstanding research by authors such as [ 5, 7, 22, 23].

In our case example FDF purchases an outcome of the service, provided by the catering operator Leijona Catering. There are two outcomes of this service purchase: firstly, FDF fills it's obligation according to national legislation to offer nutrition to every serviceman and secondly service supports the individual ca- pabilities of a single serviceman by providing a necessary nutrition and energy [24]. These outcomes form the base for the service requirements.

\section{Requirements management}

Requirements are either qualitative or quantitative properties, characteristics, expectations of the product or behaviours of the product [25]. Use of requirements management in the service development is almost self-evident. Because a value of the service is defined by the beneficiary as described by [7] this value is evaluated not how something is done but what is the outcome of the obtained service. In PBL services are defined in terms of results rather than how results are achieved. Therefore there is a need to use standards, which measure performance a system must conform in a form of requirements [26, 27].

\section{Research design}

Evidence from the previous servication studies indicates, that there should be a single "power-bythe-hour" metrics unit, which enables a transparent follow-up of the operations [28]. Purpose of the empirical research was to find statistically valid KPIs, which would meet customer, buyer and end-user requirements. In the study catering operations were defined as a supporting function for the military. This notion gave a clear framework to catering services in a military capability development framework, as stated by [29]. Although catering operations function in a peacetime environment, it obviously has a significant role in the FDF during a crises situation. This is a fact, which simply can't be ignored while studying peacetime PPP between FDF and its partners. Research framework is illustrated in the Fig. 1.

The catering operations were studied in one food service unit for a time period of five days in February 2016. Before the data collection period a restaurant manager was interviewed, recipies of each meal were researched and standardised data collection methods were agreed. This reduced the research bias during the observation period.

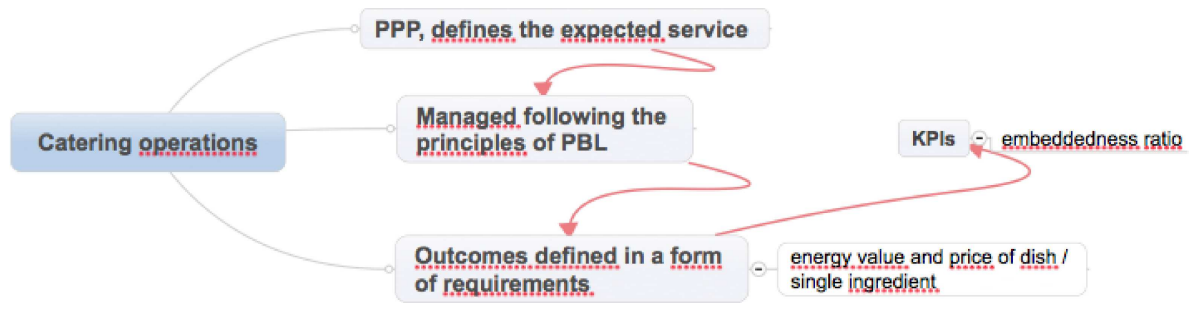

Fig. 1. Research design. 
Case unit offers its services daily approximately to 700 customers, three times a day [30]. Of these 700 customers, 40 individuals were daily randomly chosen during each meal for measuring energy (kcal), realized financial value (euros) per dish and possibly produced plate waste also in kcal and euros.

A number of observations per meal was restricted due to the research environment and restricted time frame per meal. Only background information collected from the observed servicemen was their height and weight. These figures were collected for identification purposes and for the possible further analysis.

During the data collection process authors used minimum six research assistants to collect and measure empirical data. Each research assistant used precision scale which accuracy was guaranteed by using a standardised comparison weight. Each portion in the sample was weighted before and after consumption, component by component. Results were recorded by the author and transferred to the Excel spread sheet program for the further analysis.

During the observation period service provider offered 73 breakfast items, 69 lunch items and 63 dinner items. There were 11 to 15 articles served on each meal even without separation of the ingredients in the dishes. Separation of ingredients was not necessary, because service provider had calculated energy and monetary values per dish. Also, same items such as porridge, milk and bread were served during the observation period on various meals, but they were taken into consideration during the calculations due to the energy value and cost they created. In the first phase energy and financial value sums of each observations were calculated.

Altogether there were 2 (collection and waste)*600 observations (servicemen) and each of these observations had 11-15 articles as observation points. For the each individual observation point energy value and financial value was calculated and distribution and t-tests of these values were calculated using SPSS program. Results of these tests are illustrated in the Appendices 1 and 4. If a distribution did not follow the normal distribution a box-plot analysis was conducted. Purpose of this analysis was to find the possible outliers in the data set. Results of this analysis are illustrated in the Appendix 2.

These results were compared to the figures, which form the base for the contract between FDF and a service provider. After the comparison authors studied a change to create an "embeddednes ratio", which would act as a single "power-by-the-hour" - figure. This ratio would be built using the following variables if current metrics did not provide adequate in- formation about efficiency and effectiveness of catering operations:

$\mathrm{a}=$ taken portion or ingredient calculated by the monetary value, $€$;

$\mathrm{b}=$ taken portion or ingredient calculated by the energy value, kcal;

$\mathrm{c}=$ predetermined monetary value of a portion or ingredient, $€$;

$\mathrm{d}=$ predetermined energy value of a portion or ingredient, kcal;

$\mathrm{e}=$ plate waste by energy value, $\mathrm{kcal}$;

$\mathrm{f}=$ plate waste by monetary value, $€$;

$\mathrm{g}=$ number of customers informed in advance;

$\mathrm{h}=$ actual number of customers.

\section{Results}

There were two research questions studied: Firstly, do catering operations create KPI's, which enable inter- functional co-operation and service development? Secondly, do these KPIs support both efficiency and effectiveness of PPP catering operations?

Two variables representing financial requirements and customer requirements were chosen: financial value per dish or ingredient and energy value per dish or ingredient.

These variables represented efficiency and effectiveness, respectively. Results indicate that there is a need to improve both areas. This could lead to reduced costs, enhanced efficiency and transfer operational risk in the operations previously run by the public entity.

\section{Efficiency}

Efficiency was researched by calculating variables measuring service provider's ability to produce predemanded amount of dishes for the predetermined financial value. These figures are strongly affected by the information given by the service buyer in the form of number of expected customers.

During the research period alterations of the manpower figure were between $+6 \%$ to $-19 \%$, where a negative number indicates that the actual number of customers was smaller than announced.

Second computed metrics, which affected efficiency was a plate waste created by each customer. Rationale behind this figure was that if there was no plate waste, service provider managed to offer its products efficiently. Thus, service offering was created in a manner, which was efficient, because customer (end-user) requirements in the form of energy (there was right amount food) and taste (no left-overs) were met. 
Role of plate waste was found to be almost insignificant. None of the daily observations followed the normal distribution. Amount of zero plate waste varied between 24-34 observations per meal and total amount of plate waste in kcal is very small. Results of plate waste t-tests and t-test of distribution are illustrated in the Appendix 3. Actual figures from the sample are illustrated in the Table 2.
Third computed efficiency metrics concerned the monetary value of meals, calculated by the mean sum of all ingredients each serviceman collected from the self-service line. An alarming notion was, that there were only three meals, which met predetermined financial values. Overall results are illustrated in the Table 3.

Table 2

Amount of plate waste created by the sample.

\begin{tabular}{|c|c|c|c|c|c|}
\hline & & $\begin{array}{c}\text { Plate waste (kcal) created } \\
\text { by } 40 \text { servicemen }\end{array}$ & $\begin{array}{c}\text { Offered energy/ } \\
40 \text { servicemen }\end{array}$ & $\begin{array}{c}\text { Offered } \\
- \text { plate waste }[\mathrm{kcal}]\end{array}$ & $\%$ difference \\
\hline \multirow{3}{*}{ Monday } & Breakfast & 1034 & 36160 & 35126 & 2.86 \\
\hline & Lunch & 756 & 35680 & 34924 & 2.12 \\
\hline & Dinner & 1278 & 38000 & 36722 & 3.36 \\
\hline \multirow{3}{*}{ Tuesday } & Breakfast & 347 & 34040 & 33693 & 1.02 \\
\hline & Lunch & 359 & 42800 & 42441 & 0.84 \\
\hline & Dinner & 776 & 41480 & 40704 & 1.87 \\
\hline \multirow{3}{*}{ Wednesday } & Breakfast & 3799 & 32360 & 28561 & 11.74 \\
\hline & Lunch & 2852 & 58560 & 55708 & 4.87 \\
\hline & Dinner & 3360 & 38960 & 35600 & 8.62 \\
\hline \multirow{3}{*}{ Thursday } & Breakfast & 1985 & 34760 & 32775 & 5.71 \\
\hline & Lunch & 1049 & 48040 & 46991 & 2.18 \\
\hline & Dinner & 1383 & 34640 & 33257 & 3.99 \\
\hline \multirow{3}{*}{ Friday } & Breakfast & 744 & 31240 & 30496 & 2.38 \\
\hline & Lunch & 1516 & 46000 & 44484 & 3.30 \\
\hline & Dinner & 3445 & 52000 & 48555 & 6.63 \\
\hline
\end{tabular}

Table 3

Mean financial value per meal, predetermined, difference and confidence interval (CI), values calculated as the difference between predetermined and actual in euros.

\begin{tabular}{|c|c|c|c|c|}
\hline & & Mean financial value $[\%]$ & $\begin{array}{c}\text { Difference, } \\
\text { Pre vs. mean [\%] }\end{array}$ & $\mathrm{CI}^{* *}[\%]$ \\
\hline \multirow{3}{*}{ Mon } & Breakfast & 54 & 46 & 3.2 \\
\hline & Lunch & 84 & 16 & 4.3 \\
\hline & Dinner & 94 & $6^{* * *}$ & 1.0 \\
\hline \multirow{3}{*}{ Tue } & Breakfast & 59 & 42 & 4.2 \\
\hline & Lunch & 81 & 19 & 1.6 \\
\hline & Dinner & 103 & $-3^{* * *}$ & 3.8 \\
\hline \multirow{3}{*}{ Wed } & Breakfast & 68 & 32 & 10.3 \\
\hline & Lunch & $57^{*}$ & 43 & 3.0 \\
\hline & Dinner & 91 & 9 & 11.1 \\
\hline \multirow{3}{*}{ Thu } & Breakfast & 57 & 43 & 6.2 \\
\hline & Lunch & 85 & 15 & 3.8 \\
\hline & Dinner & 91 & 9 & 6.2 \\
\hline \multirow{4}{*}{ Fri } & Breakfast & 49 & 51 & 4.0 \\
\hline & Lunch & 70 & 30 & 4.3 \\
\hline & Dinner & 112 & $-12^{* * *}$ & 8.8 \\
\hline & & $\%$ from the pre-determined & Pre vs. mean [\%] & \\
\hline
\end{tabular}

* - distribution was not normal, ** - confidence interval mean financial value taken,

*** - predetermineated financial value met 


\section{Effectiveness}

Effectiveness of the operations was calculated by the energy provided to the servicemen. Overall results are illustrated in the Table 4. Again, drastically only one meal met or exceeded the predetermined energy levels. A "Difference" variable from these effectiveness observations should be multiplied by the amount of actual customer and divided by the number of predetermined energy level, in order to follow production efficiency and to control over production.
For the further statistical analysis a one-sample T-test was run. Its results illustrated in the Appendix 4 show the confidence interval, which should be taken into consideration when comparing results.

When all the variables were added up and converted to monetary values, the total difference during the five day observation period was as high as $€ 5147,12$. This amount takes into account energy value not consumed and a mistakes in manpower figures. Kcal to $€$ conversion is illustrated on a Table 5 .

Table 4

Mean energy taken, predetermined energy, difference and confidence interval.

\begin{tabular}{|c|c|c|c|c|c|}
\hline & & $\begin{array}{l}\text { Mean energy taken }+/-\mathrm{CI}^{* *} \\
{[\mathrm{kcal}]}\end{array}$ & $\begin{array}{c}\text { Predetermined } \\
\text { Energy } \\
{[\text { kcal }]}\end{array}$ & $\begin{array}{c}\text { Difference } \\
\text { Pre vs. mean } \\
{[\text { kcal }]}\end{array}$ & $\mathrm{CI}^{* *}+/-$ \\
\hline \multirow{3}{*}{ Monday } & Breakfast & 657 & 904 & 247 & 73.844 \\
\hline & Lunch & 723 & 892 & 169 & $72 / 50$ \\
\hline & Dinner & $857^{*}$ & 950 & 93 & 79.953 \\
\hline \multirow{3}{*}{ Tuesday } & Breakfast & $534^{*}$ & 851 & 317 & 61.828 \\
\hline & Lunch & 714 & 1070 & 356 & 73.892 \\
\hline & Dinner & 797 & 1037 & 240 & 78.247 \\
\hline \multirow{3}{*}{ Wednesday } & Breakfast & 551 & 809 & 258 & 58.425 \\
\hline & Lunch & 1065 & 1464 & 399 & 105.097 \\
\hline & Dinner & 773 & 974 & 201 & 72.522 \\
\hline \multirow{3}{*}{ Thursday } & Breakfast & 512 & 869 & 357 & 52.010 \\
\hline & Lunch & 966 & 1201 & 235 & 82.567 \\
\hline & Dinner & 640 & 866 & 226 & 51.1631 \\
\hline \multirow{3}{*}{ Friday } & Breakfast & 438 & 781 & 343 & 66.970 \\
\hline & Lunch & 812 & 1150 & 338 & 63.927 \\
\hline & Dinner & 1405 & 1300 & $-105^{* * *}$ & 130.023 \\
\hline
\end{tabular}

${ }^{*}$-distribution was not normal, ${ }^{* *}$ - confidence interval mean energy taken, ${ }^{* * *}$ - predeterminated energy value met

Table 5

Kcal converted to monetary values.

\begin{tabular}{|c|c|c|c|c|c|c|c|c|}
\hline & & $\begin{array}{c}\text { Average } \\
\text { difference } \\
\text { between } \\
\text { pre-announced } \\
\text { and actual } \\
\text { consumption } \\
{[\mathrm{kcal}]} \\
\end{array}$ & $\begin{array}{c}\text { Number } \\
\text { of servicemen } \\
\text { using } \\
\text { the service }\end{array}$ & $\begin{array}{c}\text { Total } \\
\text { difference } \\
\text { in kcal }\end{array}$ & $\begin{array}{c}\text { Pre-announced } \\
\text { kcal/whole } \\
\text { meal } \\
{[\text { kcal }]}\end{array}$ & $\begin{array}{c}\text { Total } \\
\text { difference } \\
\text { in pre-announced } \\
\text { meals }\end{array}$ & $\begin{array}{c}\text { Pre-announced } \\
\text { monetary } \\
\text { value/meal } \\
\text { all ingredients } \\
{[€]}\end{array}$ & $\begin{array}{c}\text { Total } \\
\text { financial } \\
\text { effect } \\
{[€]}\end{array}$ \\
\hline \multirow{3}{*}{ Monday } & Breakfast & 247 & 933 & 230451 & 904 & 255 & 0.94 & 239.70 \\
\hline & \begin{tabular}{|l|} 
Lunch \\
\end{tabular} & 169 & 684 & 115596 & 892 & 130 & 1.82 & 236.60 \\
\hline & Dinner & 93 & 648 & 60264 & 950 & 63 & 1,17 & 73.71 \\
\hline \multirow{3}{*}{ Tuesday } & Breakfast & 317 & 749 & 237433 & 851 & 279 & 1.15 & 320.85 \\
\hline & \begin{tabular}{|l|} 
Lunch \\
\end{tabular} & 356 & 619 & 220364 & 1070 & 206 & 1.50 & 309.00 \\
\hline & Dinner & 240 & 614 & 147360 & 1037 & 142 & 1.37 & 194.54 \\
\hline \multirow{3}{*}{ Wednesday } & Breakfast & 258 & 706 & 182148 & 809 & 225 & 1.28 & 288.00 \\
\hline & \begin{tabular}{|l|} 
Lunch \\
\end{tabular} & 399 & 612 & 244188 & 1464 & 167 & 2.84 & 474.28 \\
\hline & Dinner & 201 & 748 & 150348 & 974 & 154 & 2.64 & 406.56 \\
\hline \multirow{3}{*}{ Thursday } & Breakfast & 357 & 779 & 278103 & 869 & 320 & 0.96 & 307.20 \\
\hline & Lunch & 235 & 661 & 155335 & 1201 & 129 & 0.9 & 119.97 \\
\hline & Dinner & 226 & 723 & 163398 & 866 & 189 & 1.39 & 262.71 \\
\hline \multirow{3}{*}{ Friday } & Breakfast & 343 & 824 & 282632 & 781 & 362 & 0.82 & 296.84 \\
\hline & \begin{tabular}{|l|} 
Lunch \\
\end{tabular} & 338 & 550 & 185900 & 1150 & 162 & 1.39 & 225.18 \\
\hline & Dinner & -105 & 195 & -20475 & 1300 & -16 & 1.37 & -21.92 \\
\hline
\end{tabular}




\section{Conclusion}

In the best-case situation efficiency and effectiveness figures could be used to create an "embeddedness ratio". If the optimal situation were met a figure would indicate three things. Firstly, portions' energy and monetary value would match the planned and bought outcome. Secondly, no plate waste would be created, indicating good end-user value of the provided service. Thirdly, production process would be efficient, because no over production would exist. This figure would function as a single "power-by-thehour" - figure and give a transparent and objective base for PPP development following PBL principles.

Even without a new ratio, results clearly indicate that there is a need to streamline operations and alter the principal foundation of the contract. Based on the results it can be concluded that catering operations create KPI's, which would enable inter-functional co-operation and service development with the help of "embeddedness ratio". This KPI would support both efficiency and effectiveness of PPP catering operations better than currently used individual metrics.

Current metrics are not simple, realistic, consistent and easily quantifiable and therefore they do not serve PBL purposes in the PPP between FDF and Leijona Catering.

Service provider followed its own efficiency and sales margin by each individual meal. In PBL framework this figure should be compared to the served energy value and if predetermined energy values are not met, a service provider should return an agreed amount of compensation. This is not possible if the financial deviations are not specified. Only three meals met predetermined financial value indicating overpricing of served meals.

Efficiency was affected by the FDF's own inefficiency too. Currently FDF uses only headcount of the servicemen as a base of its efficiency metrics. Duty officers inform catering unit the manpower figures calculated in the companies. Rapid changes in the training program, calculation mistakes and other human errors make this figure highly unreliable. In order to specify this figure, catering unit calculates used trays after each meal and gives a deviation figure in percentages. Both of these methods are vulnerable to inaccuracies and malpractice.

Used percentage figure told very little about efficiency in the terms of requirement set by FDF. Demand fluctuation in the observed catering unit was large. In the Monday morning restaurant served 933 servicemen and on the Friday dinner there were only 195 customers. On the other hand this Friday din- ner had the largest percentage deviation in the informed and actual customer number. Therefore the actual difference calculated by the number of customers (43 individuals) is obviously smaller despite a significantly larger percentage figure $(-19 \%)$ compared e.g. to Monday breakfast 103 individuals and $-10 \%$. Manpower alterations increase the overproduction of dishes reducing efficiency significantly.

Effectiveness of the operations was researched studying the energy values of the served dishes. Only one meal reached or exceeded the predetermined energy value. This has imminent effect to the efficiency due to the over production of food. It can be stated that in the PBL framework the service provider does not meet the service buyers or end-users' objectives.

While going through the conclusion, one has to bear in mind that this research was limited to an individual business unit within a single industry. Having said that results are very much in line with the previous researches. Examples by [31, 32] indicate both benefits of PBL and possible limitations of it which are similar to our results.

\section{Limitations of the study}

Limitations of study relate to the nature of the case study. Firstly, this study represents only one individual garrison at the capital area of Finland. Secondly, the observed food service unit is located closely to the commercial foodservices. There is a risk that consuming behavior outside the service hours makes generalization of the results more difficult. Thirdly, there is always a risk that case study in the closed environment affects the individuals, whose behavior is monitored and studied. Fourthly, a closed environment, such as garrison makes it difficult to generalize these results to the purely commercial environment.

Author used data triangulation in order to minimize all described but still possible limitations.

\section{Recommendation for the future research}

Further empirical research on the use of embeddedness ratio would increase transparency and reduce misinterpretations between stakeholders. For further studies authors recommend analysis, which would concentrate on identifying possible cluster centers from the vast amount of collected data. Cluster analysis run on all the individual cases (customers), each answer responding to individual ingredients served in the form of requirements would help 
to create more efficient and effective PPP. Also nutritional values and environmental effects of the food production could be researched using the vast empirical data. Purely customer centric survey would increase customer perspective and possibly gain service provider's efficiency and effectiveness due to better customer satisfaction. These issues were outside the

\begin{tabular}{|c|c|c|c|c|}
\hline \multicolumn{5}{|c|}{ Hypothesis Test Summary } \\
\hline & Null Hypothesis & Test & Sig. & Decision \\
\hline 1 & $\begin{array}{l}\text { The distribution of VAROOOOO3 is } \\
\text { normal with mean } 0.578 \text { and } \\
\text { standard deviation } 0,21 \text {. }\end{array}$ & $\begin{array}{l}\text { One-Sample } \\
\text { Kolmagarov } \\
\text {-Smirnov } \\
\text { Test }\end{array}$ & $.200_{1,2}$ & $\begin{array}{l}\text { Retain the } \\
\text { null the } \\
\text { hypothesis. }\end{array}$ \\
\hline 2 & $\begin{array}{l}\text { The distribution of VAROOOOO4 is } \\
\text { normal with mean } 657,016 \text { and } \\
\text { standard deviation } 230,89 \text {. }\end{array}$ & $\begin{array}{l}\text { One-Sample } \\
\text { Kolmogarov } \\
\text {-Smiirnov } \\
\text { Test }\end{array}$ &, $200_{1,2}$ & $\begin{array}{l}\text { Retain the } \\
\text { null thesis. } \\
\text { hypothesis. }\end{array}$ \\
\hline 3 & $\begin{array}{l}\text { The distribution of VAROOOOOS is } \\
\text { normal with mean } 1,516 \text { and } \\
\text { standard deviation } 0,44 .\end{array}$ & $\begin{array}{l}\text { One-Sample } \\
\text { Kolmagarov } \\
\text {-Smiirnov } \\
\text { Test }\end{array}$ & $200_{1,2}$ & $\begin{array}{l}\text { Retain the } \\
\text { null thesis. } \\
\text { hypothesis. }\end{array}$ \\
\hline 4 & $\begin{array}{l}\text { The distribution of VAROOOOG is } \\
\text { normal with mean } 723,679 \text { and } \\
\text { standard deviation } 226,69 \text {. }\end{array}$ & $\begin{array}{l}\text { One-Sample } \\
\text { Kolmagarov } \\
\text {-Smirnov } \\
\text { Test }\end{array}$ &, $200_{1,2}$ & $\begin{array}{l}\text { Retain the } \\
\text { null thesis. } \\
\text { hypothesis. }\end{array}$ \\
\hline 5 & $\begin{array}{l}\text { The distribution of VAROOOOO is } \\
\text { normal with mean } 1,096 \text { and } \\
\text { standard deviation } 0,33 \text {. }\end{array}$ & $\begin{array}{l}\text { One-Sample } \\
\text { Kolmagarov } \\
\text {-Smiirnov } \\
\text { Test }\end{array}$ &, $200_{1,2}$ & $\begin{array}{l}\text { Retain the } \\
\text { null the } \\
\text { hypothesis. }\end{array}$ \\
\hline 6 & $\begin{array}{l}\text { The distribution of } \mathrm{VAROOOOOB} \text { is } \\
\text { normal with mean } 85.432 \text { and } \\
\text { standard deviation } 250,00 \text {. }\end{array}$ & $\begin{array}{l}\text { One-Sample } \\
\text { Kolmagarov } \\
\text {-Smirnov } \\
\text { Test }\end{array}$ & $200_{1,2}$ & $\begin{array}{l}\text { Reject the } \\
\text { null thesis. } \\
\text { hypothes }\end{array}$ \\
\hline 7 & $\begin{array}{l}\text { The distribution of VAROOOOO is } \\
\text { normal with mean } 0.675 \text { and } \\
\text { standard deviation } 0,28 \text {. }\end{array}$ & $\begin{array}{l}\text { One-Sample } \\
\text { Kolmagarov } \\
\text {-Smirnov } \\
\text { Test }\end{array}$ & $.200_{1,2}$ & $\begin{array}{l}\text { Retain the } \\
\text { null the } \\
\text { hypothesis. }\end{array}$ \\
\hline 8 & $\begin{array}{l}\text { The distribution of VAROOO10 is } \\
\text { normal with mean } 534,832 \text { and } \\
\text { standard deviation } 193,32 \text {. }\end{array}$ & $\begin{array}{l}\text { One-Sample } \\
\text { Kolmagarov } \\
\text {-Smiirnov } \\
\text { Test }\end{array}$ & $200_{1,2}$ & $\begin{array}{l}\text { Reject the } \\
\text { null thesis. } \\
\text { hypothes. }\end{array}$ \\
\hline 9 & $\begin{array}{l}\text { The distribution of VAROOO11 is } \\
\text { normal with mean } 1.217 \text { and } \\
\text { standard deviation } 0,37 \text {. }\end{array}$ & $\begin{array}{l}\text { One-Sample } \\
\text { Kolmagarov } \\
\text {-Smiirnov } \\
\text { Test }\end{array}$ & $.200_{1,2}$ & $\begin{array}{l}\text { Retain the } \\
\text { null the } \\
\text { hypothesis. }\end{array}$ \\
\hline 10 & $\begin{array}{l}\text { The distribution of VAROOO12 is } \\
\text { normal with mean } 714,498 \text { and } \\
\text { standard deviation } 231,05 \text {. }\end{array}$ & $\begin{array}{l}\text { One-Sample } \\
\text { Kolmagarov } \\
\text {-Smiirnov } \\
\text { Test }\end{array}$ & $200_{1,2}$ & $\begin{array}{l}\text { Retain the } \\
\text { null the } \\
\text { hypothesis. }\end{array}$ \\
\hline 11 & $\begin{array}{l}\text { The distribution of VAROOO13 is } \\
\text { normal with mean } 1.412 \text { and } \\
\text { standard deviation } 0,50 .\end{array}$ & $\begin{array}{l}\text { One-Sample } \\
\text { Kolmagarov } \\
\text {-Smiirnov } \\
\text { Test }\end{array}$ & $200_{1,2}$ & $\begin{array}{l}\text { Retain the } \\
\text { null the } \\
\text { hypothesis. }\end{array}$ \\
\hline \multicolumn{5}{|c|}{$\begin{array}{l}\text { Asymptotic significances are displayed. The significance level is , } 05 \text {. } \\
{ }_{1} \text { Lilliefors Corrected }\end{array}$} \\
\hline \multicolumn{5}{|c|}{$\begin{array}{l}{ }_{2} \text { This is a lower bound of the true significance. } \\
\text { Hypothesis Test Summary }\end{array}$} \\
\hline & Null Hypothes is & Test & Sig. & Decision \\
\hline 21 & $\begin{array}{l}\text { The distribution of VAROD023 is } \\
\text { normal with mean } 0,821 \text { and } \\
\text { standard deviation } 0,29 \text {. }\end{array}$ & $\begin{array}{l}\text { One-Sample } \\
\text { Kolmogorov } \\
\text {-Smirnov } \\
\text { Test }\end{array}$ & $.200_{1,2}$ & $\begin{array}{l}\text { Retain the } \\
\text { null thes } \\
\text { hypothesis. }\end{array}$ \\
\hline 22 & $\begin{array}{l}\text { The distribution of VARO0024 is } \\
\text { normal with mean } 966,902 \text { and } \\
\text { standard deviation } 258,17 \text {. }\end{array}$ & $\begin{array}{l}\text { One-Sample } \\
\text { Kolmogorov } \\
\text {-Smirnov } \\
\text { Test }\end{array}$ & $.200_{1,2}$ & $\begin{array}{l}\text { Retain the } \\
\text { null the } \\
\text { hypothesis. }\end{array}$ \\
\hline 23 & $\begin{array}{l}\text { The distribution of VARO0025 is } \\
\text { normal with mean } 1,256 \text { and } \\
\text { standard deviation } 0,35 \text {. }\end{array}$ & $\begin{array}{l}\text { One-Sample } \\
\text { Kolmogorov } \\
\text {-Smimov } \\
\text { Test }\end{array}$ &, $200_{1,2}$ & $\begin{array}{l}\text { Retain the } \\
\text { null } \\
\text { hypothesis. }\end{array}$ \\
\hline 24 & $\begin{array}{l}\text { The distribution of VAROD026 is } \\
\text { normal with mean } 648,444 \text { and } \\
\text { standard deviation } 159,98 \text {. }\end{array}$ & $\begin{array}{l}\text { One-Sample } \\
\text { Kolmogorov } \\
\text {-Smimov } \\
\text { Test }\end{array}$ &, $200_{1,2}$ & $\begin{array}{l}\text { Retain the } \\
\text { null thothesis. } \\
\text { hypothes. }\end{array}$ \\
\hline 25 & $\begin{array}{l}\text { The distribution of VARODO027 is } \\
\text { normal with mean } 0,404 \text { and } \\
\text { standard deviation } 0,23 \text {. }\end{array}$ & $\begin{array}{l}\text { One-Sample } \\
\text { Kolmogorov } \\
\text {-Smirnov } \\
\text { Test }\end{array}$ &, $200_{1,2}$ & $\begin{array}{l}\text { Retain the } \\
\text { null } \\
\text { hypothesis. }\end{array}$ \\
\hline 26 & $\begin{array}{l}\text { The distribution of VARO0028 is } \\
\text { normal with mean } 438,172 \text { and } \\
\text { standard deviation } 209,40 \text {. }\end{array}$ & $\begin{array}{l}\text { One-Sample } \\
\text { Kolmogorov } \\
\text {-Smirnov } \\
\text { Test }\end{array}$ &, $200_{1,2}$ & $\begin{array}{l}\text { Retain the } \\
\text { null thesis. } \\
\text { hypothes. }\end{array}$ \\
\hline 27 & $\begin{array}{l}\text { The distribution of VARO0029 is } \\
\text { normal with mean } 0,966 \text { and } \\
\text { standard deviation } 0,31 \text {. }\end{array}$ & $\begin{array}{l}\text { One-Sample } \\
\text { Kolmogorov } \\
\text {-Smiirnov } \\
\text { Test }\end{array}$ &, $200_{1,2}$ & $\begin{array}{l}\text { Retain the } \\
\text { null thesis. } \\
\text { hypothes. }\end{array}$ \\
\hline 28 & $\begin{array}{l}\text { The distribution of VARO00030 is } \\
\text { normal with mean } 812,390 \text { and } \\
\text { standard deviation } 199,89 \text {. }\end{array}$ & $\begin{array}{l}\text { One-Sample } \\
\text { Kolmogorov } \\
\text {-Smirnov } \\
\text { Test }\end{array}$ &, $200_{1,2}$ & $\begin{array}{l}\text { Retain the } \\
\text { null } \\
\text { hypothesis. }\end{array}$ \\
\hline
\end{tabular}

scope of this research but they can't be neglected in the future research.

\section{Appendix 1}

Test of normal distribution, kcal and monetary value of taken meals.

\begin{tabular}{|c|c|c|c|c|}
\hline \multicolumn{5}{|c|}{ Hypothesis Test Summary } \\
\hline & Null Hypothesis & Test & Sig. & Decision \\
\hline 12 & $\begin{array}{l}\text { The distribution of VARO0014 is } \\
\text { normal with mean } 797,84 \text { and } \\
\text { standard deviation } 244,66 \text {. }\end{array}$ & $\begin{array}{l}\text { One-Sample } \\
\text { Kolmogorov } \\
\text {-Smimov } \\
\text { Test }\end{array}$ &, $200_{1,2}$ & $\begin{array}{l}\text { Retain the } \\
\text { null } \\
\text { hypothesis. }\end{array}$ \\
\hline 13 & $\begin{array}{l}\text { The distribution of VARO0015 is } \\
\text { normal with mean } 0,874 \text { and } \\
\text { standard deviation } 0,30 \text {. }\end{array}$ & $\begin{array}{l}\text { One-Sarmple } \\
\text { Kolmogorov } \\
\text {-Smirnov } \\
\text { Test }\end{array}$ & $.200_{1,2}$ & $\begin{array}{l}\text { Retain the } \\
\text { null } \\
\text { hypothesis. }\end{array}$ \\
\hline 14 & $\begin{array}{l}\text { The distribution of VAROOOD16 is } \\
\text { normal with mean } 551,914 \text { and } \\
\text { standard deviation } 182,68 \text {. }\end{array}$ & $\begin{array}{l}\text { One-Sample } \\
\text { Kolmogorov } \\
\text {-Smirnov } \\
\text { Test }\end{array}$ &, $200_{1,2}$ & $\begin{array}{l}\text { Retain the } \\
\text { null } \\
\text { hypothesis. }\end{array}$ \\
\hline 15 & $\begin{array}{l}\text { The distribution of VARO0017 is } \\
\text { normal with mean } 1,613 \text { and } \\
\text { standard deviation } 0,62 \text {. }\end{array}$ & $\begin{array}{l}\text { One-Sample } \\
\text { Kolmogorov } \\
\text {-Smirnov } \\
\text { Test }\end{array}$ &, $200_{1,2}$ & $\begin{array}{l}\text { Reject the } \\
\text { null } \\
\text { hypothesis. }\end{array}$ \\
\hline 16 & $\begin{array}{l}\text { The distribution of VARO00018 is } \\
\text { normal with mean } 1020,890 \text { and } \\
\text { standard deviation } 328,62 \text {. }\end{array}$ & $\begin{array}{l}\text { One-Sample } \\
\text { Kolmogorov } \\
\text { - Smimov } \\
\text { Test }\end{array}$ & $.200_{1,2}$ & $\begin{array}{l}\text { Retain the } \\
\text { null } \\
\text { hypothesis. }\end{array}$ \\
\hline 17 & $\begin{array}{l}\text { The distribution of VARO0019 is } \\
\text { normal with mean } 2,389 \text { and } \\
\text { standard deviation } 0,70 \text {. }\end{array}$ & $\begin{array}{l}\text { One-Sample } \\
\text { Kolmogorov } \\
\text {-Smirnov } \\
\text { Test }\end{array}$ &, $200_{1,2}$ & $\begin{array}{l}\text { Retain the } \\
\text { null } \\
\text { hypothesis. }\end{array}$ \\
\hline 18 & $\begin{array}{l}\text { The distribution of VARO0020 is } \\
\text { normal with mean } 773,364 \text { and } \\
\text { standard deviation } 226,76 \text {. }\end{array}$ & $\begin{array}{l}\text { One-Sample } \\
\text { Kolmagorov } \\
\text {-Smirnov } \\
\text { Test }\end{array}$ &, $200_{1,2}$ & $\begin{array}{l}\text { Retain the } \\
\text { null } \\
\text { hypothesis. }\end{array}$ \\
\hline 19 & $\begin{array}{l}\text { The distribution of VARO0021 is } \\
\text { normal with mean } 0,554 \text { and } \\
\text { standard deviation } 0,19 \text {. }\end{array}$ & $\begin{array}{l}\text { One-Sample } \\
\text { Kolmogorov } \\
\text {-Smimov } \\
\text { Test }\end{array}$ &, $200_{1,2}$ & $\begin{array}{l}\text { Retain the } \\
\text { null } \\
\text { hypothesis. }\end{array}$ \\
\hline 20 & $\begin{array}{l}\text { The distribution of VARO0022 is } \\
\text { normal with mean } 512,726 \text { and } \\
\text { standard deviation } 162,62 \text {. }\end{array}$ & $\begin{array}{l}\text { One-Sample } \\
\text { Kolmogorov } \\
\text {-Smirnov } \\
\text { Test }\end{array}$ &, $200_{1,2}$ & $\begin{array}{l}\text { Retain the } \\
\text { null } \\
\text { hypothesis. }\end{array}$ \\
\hline
\end{tabular}

Hypothesis Test Summary

\begin{tabular}{|c|c|c|c|c|}
\hline & Null Hypothesis & Test & Sig. & Decision \\
\hline 29 & $\begin{array}{l}\text { The distribution of VARO00031 is } \\
\text { normal with mean } 1,535 \text { and } \\
\text { standard deviation } 0,44 .\end{array}$ & $\begin{array}{l}\text { One-Sample } \\
\text { Kolmogorov } \\
\text {-Smirnov } \\
\text { Test }\end{array}$ &, $200_{1,2}$ & $\begin{array}{l}\text { Retain the } \\
\text { null the } \\
\text { hypothes is. }\end{array}$ \\
\hline 30 & $\begin{array}{l}\text { The distribution of VAR00032 is } \\
\text { normal with mean } 1405,306 \text { and } \\
\text { standard deviation } 406,56 .\end{array}$ & $\begin{array}{l}\text { One-Sample } \\
\text { Kolmogorov } \\
\text {-Smirnov } \\
\text { Test }\end{array}$ & $200_{1,2}$ & $\begin{array}{l}\text { Retain the } \\
\text { null thes } \\
\text { hypothes. }\end{array}$ \\
\hline
\end{tabular}




\section{Appendix 2}

Test of outliers, observations which did not follow normal distribution.
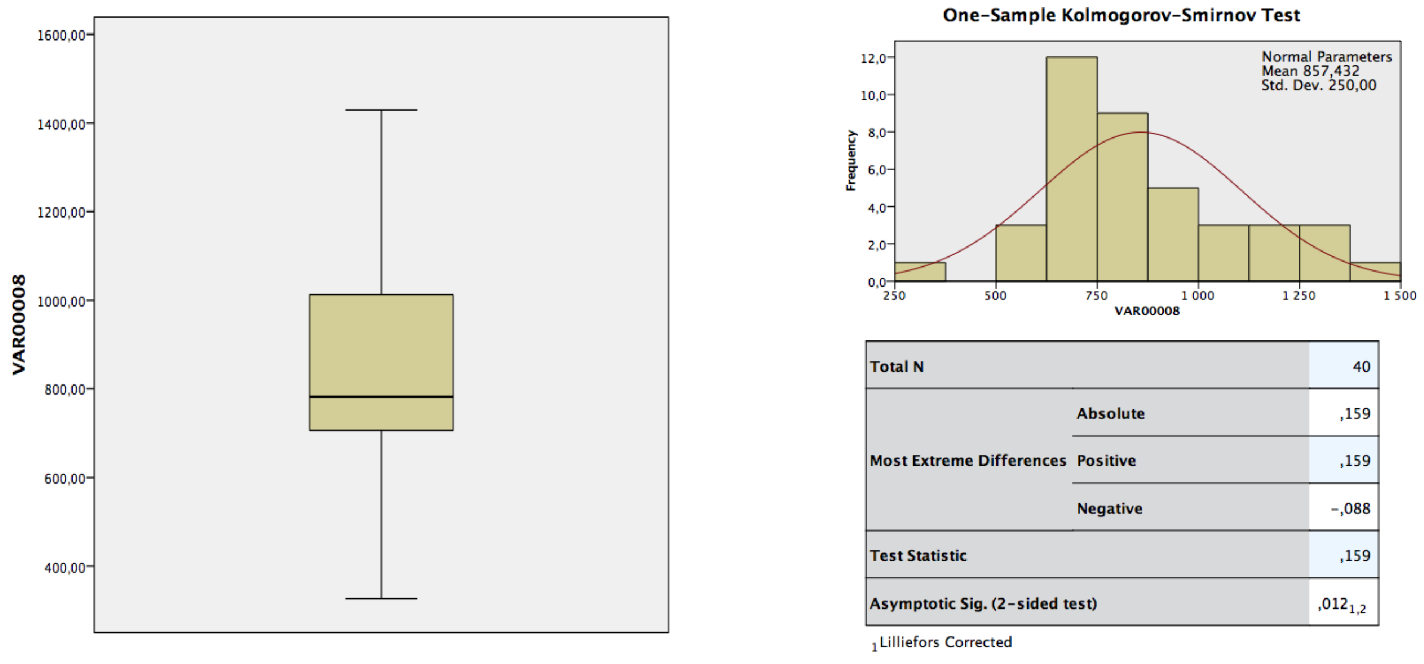

${ }_{2}$ This is a lower bound of the true significance.
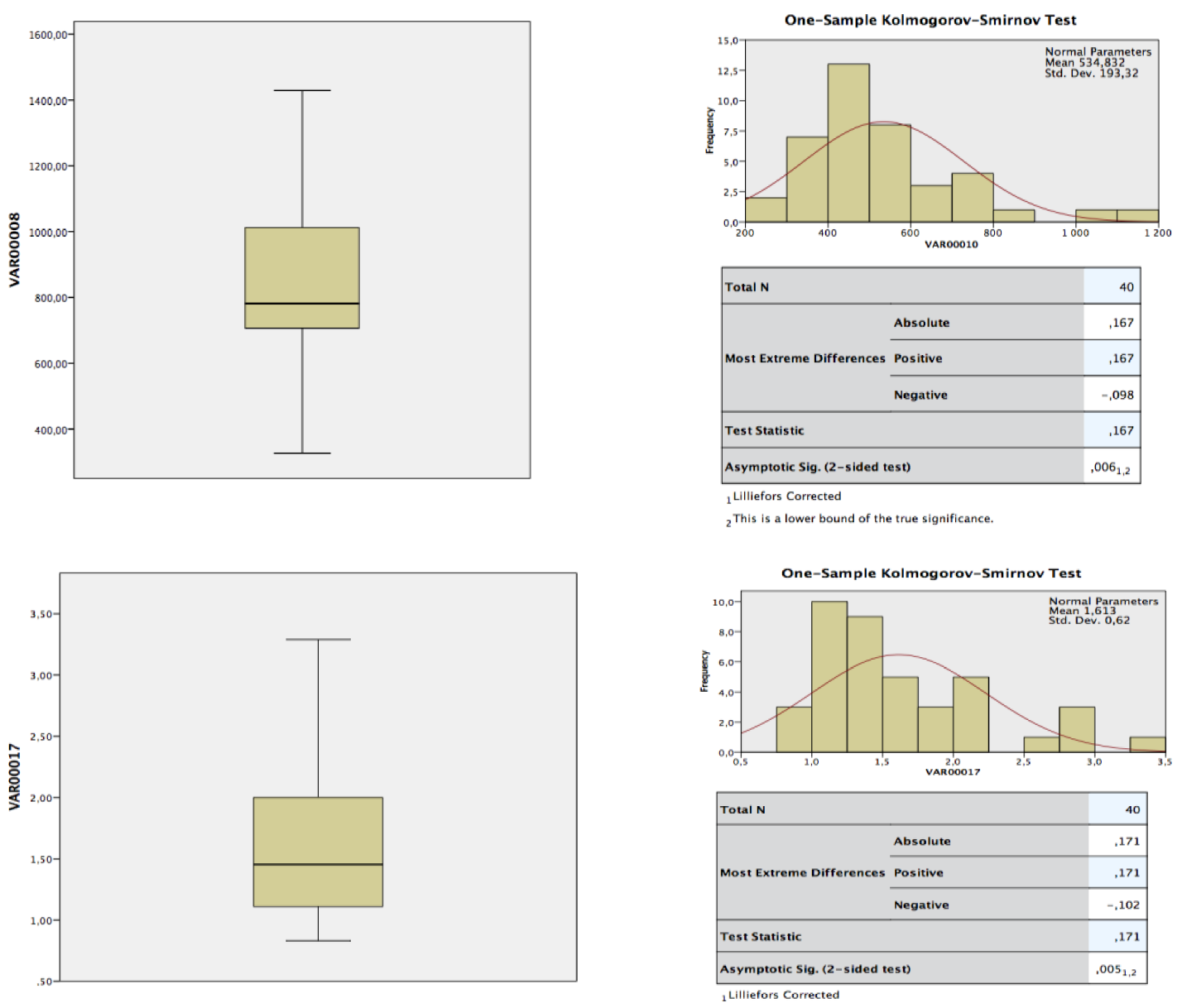

This is a lower bound of the true significance. 
Management and Production Engineering Review

\section{Appendix 3}

T-test and test of distribution for plate waste values.

One-Sample Test

\begin{tabular}{|c|c|c|c|c|c|c|}
\hline & \multicolumn{6}{|c|}{ Test Value $=0$} \\
\hline & \multirow{2}{*}{$\mathrm{t}$} & \multirow{2}{*}{ df } & \multirow{2}{*}{ Sig. (2-tailed) } & \multirow{2}{*}{ Mean Difference } & \multicolumn{2}{|c|}{ 95\% Confidence Interval of the Difference } \\
\hline & & & & & Lower & Upper \\
\hline Mon, ${ }^{*} \mathrm{~B}, €$ & 3,694 & 39 & ,001 & 03125 &, 0141 &, 0484 \\
\hline Mon, B, kcal & 4,007 & 39 &, 000 & 25,84925 & 12,8003 & 38,8982 \\
\hline Mon, ${ }^{*} \mathrm{~L}, €$ & 2,276 & 39 &, 028 &, 04350 &, 0048 &, 0822 \\
\hline Mon, L, kcal & 2,006 & 39 & ,052 & 18,89725 &,- 1601 & 37,9546 \\
\hline Mon, $* \mathrm{D}, €$ & 1,837 & 39 &, 074 &, 00550 &,- 0006 &, 0116 \\
\hline Mon, D, kcal & 2,121 & 39 &, 040 & 31,94950 & 1,4814 & 62,4176 \\
\hline Tue, B, $€$ & 2,428 & 39 &, 020 &, 02875 &, 0048 &, 0527 \\
\hline Tue B, kcal & 2,664 & 39 &, 011 & 8,67575 & 2,0896 & 15,2619 \\
\hline Tue, L, $€$ & 2,456 & 39 &, 019 &, 01450 &, 0026 &, 0264 \\
\hline Tue, L, kcal & 2,705 & 39 &, 010 & 8,96725 & 2,2611 & 15,6734 \\
\hline Tue, $\mathrm{D}, €$ & 2,010 & 39 &, 051 &, 02600 &,- 0002 &, 0522 \\
\hline Tue, D, kcal & 2,265 & 39 &, 029 & 19,39025 & 2,0736 & 36,7069 \\
\hline Wed, B, € & 4,485 & 39 &, 000 & , 14675 &, 0806 &, 2129 \\
\hline Wed B, kcal & 4,483 & 39 &, 000 & 94,98600 & 52,1253 & 137,8467 \\
\hline Wed,L, € & 2,968 & 39 &, 005 &, 06175 & ,0197 &, 1038 \\
\hline Wed, L, kcal & 3,465 & 39 &, 001 & 71,30575 & 29,6791 & 112,9324 \\
\hline Wed, D, € & 4,630 & 39 & ,000 &, 33650 & , 1895 &, 4835 \\
\hline Wed D, kcal & 5,209 & 39 &, 000 & 84,00050 & 51,3855 & 116,6155 \\
\hline Thu, B, € & 3,041 & 39 &, 004 &, 04500 &, 0151 &, 0749 \\
\hline Thu, B, kcal & 2,888 & 39 &, 006 & 49,62525 & 14,8654 & 84,3851 \\
\hline Thu, L, $€$ & 2,222 & 39 &, 032 & ,02000 & ,0018 & , 0382 \\
\hline Thu, L, kcal & 2,388 & 39 &, 022 & 26,23675 & 4,0164 & 48,4571 \\
\hline Thu, D, $€$ & 3,049 & 39 &, 004 &, 06550 &, 0221 &, 1089 \\
\hline Thu D, kcal & 3,046 & 39 &, 004 & 34,57125 & 11,6152 & 57,5273 \\
\hline Fri, B, € & 2,140 & 39 &, 039 &, 01725 &, 0009 &, 0336 \\
\hline Fri, B, kcal & 2,940 & 39 &, 005 & 18,60850 & 5,8078 & 31,4092 \\
\hline Fri, L, € & 2,458 & 39 & ,019 &, 03600 & ,0064 & ,0656 \\
\hline Fri, L, kcal & 3,142 & 39 &, 003 & 37,90875 & 13,5052 & 62,3123 \\
\hline Fri, D, $€$ & 2,956 & 39 &, 005 &, 08850 &, 0280 &, 1490 \\
\hline Fri, D, kcal & 3,127 & 39 & ,003 & 86,11950 & 30,4181 & 141,8209 \\
\hline
\end{tabular}

${ }^{*} \mathrm{~B}$ - breakfast, $\mathrm{L}-$ lunch, $\mathrm{D}-$ dinner. 
Management and Production Engineering Review

Hypothesis Test Summary

\begin{tabular}{|c|c|c|c|c|}
\hline & Null Hypothesis & Test & Sig. & Decision \\
\hline 1 & $\begin{array}{l}\text { The distribution of VARODOO1 is } \\
\text { normal with mean } 0,031 \text { and } \\
\text { standard deviation } 0,05 \text {. }\end{array}$ & $\begin{array}{l}\text { One-Sample } \\
\text { Kolmagorov } \\
\text {-Smirnov } \\
\text { Test }\end{array}$ &, $000_{1}$ & $\begin{array}{l}\text { Reject the } \\
\text { null thesis. } \\
\text { hypothesis. }\end{array}$ \\
\hline 2 & $\begin{array}{l}\text { The distribution of VAROOOO2 is } \\
\text { normal with mean } 25,849 \text { and } \\
\text { standard deviation } 40,80 \text {. }\end{array}$ & $\begin{array}{l}\text { One-Sample } \\
\text { Kolmagorov } \\
\text {-Smirnov } \\
\text { Test }\end{array}$ &, $000_{1}$ & $\begin{array}{l}\text { Reject the } \\
\text { null the } \\
\text { hypothesis. }\end{array}$ \\
\hline 3 & $\begin{array}{l}\text { The distribution of VAROOOOO is } \\
\text { normal with mean } 0,044 \text { and } \\
\text { standard deviation } 0,12 \text {. }\end{array}$ & $\begin{array}{l}\text { One-Sample } \\
\text { Kolmagorov } \\
\text {-Smirnov } \\
\text { Test }\end{array}$ &, $000_{1}$ & $\begin{array}{l}\text { Reject the } \\
\text { null thes } \\
\text { hypothesis. }\end{array}$ \\
\hline 4 & $\begin{array}{l}\text { The distribution of VARODOOO is } \\
\text { normal with mean } 18,897 \text { and } \\
\text { standard deviation } 59,59 \text {. }\end{array}$ & $\begin{array}{l}\text { One-Sample } \\
\text { Kolmagorov } \\
\text {-Smirnov } \\
\text { Test }\end{array}$ &, $000_{1}$ & $\begin{array}{l}\text { Reject the } \\
\text { null the } \\
\text { hypothesis. }\end{array}$ \\
\hline 5 & $\begin{array}{l}\text { The distribution of VAROOOOS is } \\
\text { normal with mean } 0,006 \text { and } \\
\text { standard deviation } 0,02 \text {. }\end{array}$ & $\begin{array}{l}\text { One-Sample } \\
\text { Kolmogorov } \\
\text { =Smirnov } \\
\text { Test }\end{array}$ & $.000_{1}$ & $\begin{array}{l}\text { Reject the } \\
\text { null the } \\
\text { hypothesis. }\end{array}$ \\
\hline 6 & $\begin{array}{l}\text { The distribution of VAROOOO6 is } \\
\text { normal with mean } 31,950 \text { and } \\
\text { standard deviation } 95,27 \text {. }\end{array}$ & $\begin{array}{l}\text { One-Sample } \\
\text { Kolmagorov } \\
\text { =Smirnov } \\
\text { Test }\end{array}$ &, $000_{1}$ & $\begin{array}{l}\text { Reject the } \\
\text { null thes } \\
\text { hypothesis. }\end{array}$ \\
\hline 7 & $\begin{array}{l}\text { The distribution of VAROOOOO7 is } \\
\text { normal with mean } 0,029 \text { and } \\
\text { standard deviation } 0,07 \text {. }\end{array}$ & $\begin{array}{l}\text { One-Sample } \\
\text { Kolmagorov } \\
\text {-Smirnov } \\
\text { Test }\end{array}$ &, $000_{1}$ & $\begin{array}{l}\text { Reject the } \\
\text { null thesis. } \\
\text { hypothes }\end{array}$ \\
\hline 8 & $\begin{array}{l}\text { The distribution of VAROOOOOS is } \\
\text { normal with mean } 8,676 \text { and } \\
\text { standard deviation } 20,59 \text {. }\end{array}$ & $\begin{array}{l}\text { One-Sample } \\
\text { Kolmagorov } \\
\text {-Smirnov } \\
\text { Test }\end{array}$ & $.000_{1}$ & $\begin{array}{l}\text { Reject the } \\
\text { null thesis. } \\
\text { hypothes }\end{array}$ \\
\hline 9 & $\begin{array}{l}\text { The distribution of VAROOOOO9 is } \\
\text { normal with mean } 0,014 \text { and } \\
\text { standard deviation } 0,04 \text {. }\end{array}$ & $\begin{array}{l}\text { One-Sample } \\
\text { Kolmagorov } \\
\text {-Smirnov } \\
\text { Test }\end{array}$ & $.000_{1}$ & $\begin{array}{l}\text { Reject the } \\
\text { null the } \\
\text { hypothesis. }\end{array}$ \\
\hline 10 & $\begin{array}{l}\text { The distribution of VAROOO10 is } \\
\text { normal with mean } 8,967 \text { and } \\
\text { standard deviation } 20,97 \text {. }\end{array}$ & $\begin{array}{l}\text { One-Sample } \\
\text { Kolmagorov } \\
\text {-Smimov } \\
\text { Test }\end{array}$ &, $000_{1}$ & $\begin{array}{l}\text { Reject the } \\
\text { null thesis. } \\
\text { hypothesi }\end{array}$ \\
\hline 11 & $\begin{array}{l}\text { The distribution of VAROOOO11 is } \\
\text { normal with mean } 0,026 \text { and } \\
\text { standard deviation } 0,08 \text {. }\end{array}$ & $\begin{array}{l}\text { One-Sample } \\
\text { Kolmagorov } \\
\text {-Smirnov }\end{array}$ & $.000_{1}$ & $\begin{array}{l}\text { Reject the } \\
\text { null thes is. } \\
\text { hypothet }\end{array}$ \\
\hline
\end{tabular}

Hypothesis Test Summary

\begin{tabular}{|c|c|c|c|c|}
\hline & Null Hypothesis & Test & Sig. & Decision \\
\hline 12 & $\begin{array}{l}\text { The distribution of VAR00012 is } \\
\text { normal with mean } 19,390 \text { and } \\
\text { standard deviation } 54,15 \text {. }\end{array}$ & $\begin{array}{l}\text { One-Sample } \\
\text { Kolmogorov } \\
\text {-Smirnov } \\
\text { Test }\end{array}$ &, $000_{1}$ & $\begin{array}{l}\text { Reject the } \\
\text { null } \\
\text { hypothesis. }\end{array}$ \\
\hline 13 & $\begin{array}{l}\text { The distribution of VARO0013 is } \\
\text { normal with mean } 0,147 \text { and } \\
\text { standard deviation } 0,21 \text {. }\end{array}$ & $\begin{array}{l}\text { One-Sample } \\
\text { Kolmogorov } \\
\text {-Smirnov } \\
\text { Test }\end{array}$ &, $000_{1}$ & $\begin{array}{l}\text { Reject the } \\
\text { null } \\
\text { hypothesis. }\end{array}$ \\
\hline 14 & $\begin{array}{l}\text { The distribution of VAR00014 is } \\
\text { normal with mean } 94,968 \text { and } \\
\text { standard deviation } 134,02 \text {. }\end{array}$ & $\begin{array}{l}\text { One-Sample } \\
\text { Kolmogorov } \\
\text {-Smirnov } \\
\text { Test }\end{array}$ &, $000_{1}$ & $\begin{array}{l}\text { Reject the } \\
\text { null } \\
\text { hypothesis. }\end{array}$ \\
\hline 15 & $\begin{array}{l}\text { The distribution of VAR00015 is } \\
\text { normal with mean } 0,062 \text { and } \\
\text { standard deviation } 0,13 \text {. }\end{array}$ & $\begin{array}{l}\text { One-Sample } \\
\text { Kolmagorov } \\
\text {-Smirnov } \\
\text { Test }\end{array}$ &, $000_{1}$ & $\begin{array}{l}\text { Reject the } \\
\text { null } \\
\text { hypothesis. }\end{array}$ \\
\hline 16 & $\begin{array}{l}\text { The distribution of VAR00016 is } \\
\text { normal with mean } 71,306 \text { and } \\
\text { standard deviation } 130,16 \text {. }\end{array}$ & $\begin{array}{l}\text { One-Sample } \\
\text { Kolmogorov } \\
\text {-Smirnov } \\
\text { Test }\end{array}$ &, $000_{1}$ & $\begin{array}{l}\text { Reject the } \\
\text { null } \\
\text { hypothesis. }\end{array}$ \\
\hline 17 & $\begin{array}{l}\text { The distribution of VAR00017 is } \\
\text { nermal with mean } 0,336 \text { and } \\
\text { standard deviation } 0,46 \text {. }\end{array}$ & $\begin{array}{l}\text { One-Sample } \\
\text { Kolmogorov } \\
\text {-Smirnov } \\
\text { Test }\end{array}$ &, $000_{1}$ & $\begin{array}{l}\text { Reject the } \\
\text { null } \\
\text { hypothesis. }\end{array}$ \\
\hline 18 & $\begin{array}{l}\text { The distribution of VAR00018 is } \\
\text { normal with mean } 84,000 \text { and } \\
\text { standard deviation } 101,98 \text {. }\end{array}$ & $\begin{array}{l}\text { One-Sample } \\
\text { Kolmogorov } \\
\text {-Smirnov } \\
\text { Test }\end{array}$ &, $000_{1}$ & $\begin{array}{l}\text { Reject the } \\
\text { null } \\
\text { hypothesis. }\end{array}$ \\
\hline 19 & $\begin{array}{l}\text { The distribution of VAR00019 is } \\
\text { normal with mean } 0,045 \text { and } \\
\text { standard deviation } 0,09 \text {. }\end{array}$ & $\begin{array}{l}\text { One-Sample } \\
\text { Kolmogorov } \\
\text {-Smirnov } \\
\text { Test }\end{array}$ &, $000_{1}$ & $\begin{array}{l}\text { Reject the } \\
\text { null } \\
\text { hypothesis. }\end{array}$ \\
\hline 20 & $\begin{array}{l}\text { The distribution of VAR00020 is } \\
\text { normal with mean } 49,625 \text { and } \\
\text { standard deviation } 108,69 \text {. }\end{array}$ & $\begin{array}{l}\text { One-Sample } \\
\text { Kolmogorov } \\
\text {-Smirnov } \\
\text { Test }\end{array}$ &, $000_{1}$ & $\begin{array}{l}\text { Reject the } \\
\text { null } \\
\text { hypothesis. }\end{array}$ \\
\hline
\end{tabular}

Asymptotic significances are displayed. The significance level is , 05 .
Hypothesis Test Summary

\begin{tabular}{|c|c|c|c|c|}
\hline & Null Hypothesis & Test & Sig. & Decision \\
\hline 21 & $\begin{array}{l}\text { The distribution of VAROOOO21 is } \\
\text { normal with mean } 0,020 \text { and } \\
\text { standard deviation } 0,06 \text {. }\end{array}$ & $\begin{array}{l}\text { One-Sample } \\
\text { Kolmogorav } \\
\text {-Smirnov } \\
\text { Test }\end{array}$ & $.000_{1}$ & $\begin{array}{l}\text { Reject the } \\
\text { null thesis. } \\
\text { hypothesis. }\end{array}$ \\
\hline 22 & $\begin{array}{l}\text { The distribution of VARO0022 is } \\
\text { normal with mean } 26,237 \text { and } \\
\text { standard deviation } 69,48 \text {. }\end{array}$ & $\begin{array}{l}\text { One-Sample } \\
\text { Kolmogorov } \\
\text {-Smirnov } \\
\text { Test }\end{array}$ &, $000_{1}$ & $\begin{array}{l}\text { Reject the } \\
\text { null the } \\
\text { hypothesis. }\end{array}$ \\
\hline 23 & $\begin{array}{l}\text { The distribution of VAROO0023 is } \\
\text { normal with mean } 0,066 \text { and } \\
\text { standard deviation } 0,14 .\end{array}$ & $\begin{array}{l}\text { One-Sample } \\
\text { Kolmagorov } \\
\text {-Smirnov } \\
\text { Test }\end{array}$ & $.000_{1}$ & $\begin{array}{l}\text { Reject the } \\
\text { null the } \\
\text { hypothesis. }\end{array}$ \\
\hline 24 & $\begin{array}{l}\text { The distribution of VAROOO224 is } \\
\text { normal with mean } 34,571 \text { and } \\
\text { standard deviation } 71,78 \text {. }\end{array}$ & $\begin{array}{l}\text { One-Sample } \\
\text { Kolmogorov } \\
\text {-Smirnov } \\
\text { Test }\end{array}$ &, $000_{1}$ & $\begin{array}{l}\text { Reject the } \\
\text { null theshis. } \\
\text { hypothesi }\end{array}$ \\
\hline 25 & $\begin{array}{l}\text { The distribution of VARO0025 is } \\
\text { normal with mean } 0,017 \text { and } \\
\text { standard deviation } 0,05 \text {. }\end{array}$ & $\begin{array}{l}\text { One-Sample } \\
\text { Kolmagorav } \\
\text {-Smirnov } \\
\text { Test }\end{array}$ &, $000_{1}$ & $\begin{array}{l}\text { Reject the } \\
\text { null thes is. } \\
\text { hypothes. }\end{array}$ \\
\hline 26 & $\begin{array}{l}\text { The distribution of VAROOOO26 is } \\
\text { normal with mean } 18,608 \text { and } \\
\text { standard deviation } 40,03 \text {. }\end{array}$ & $\begin{array}{l}\text { One-Sample } \\
\text { Kolmogorov } \\
\text {-Smirnov } \\
\text { Test }\end{array}$ &, $000_{1}$ & $\begin{array}{l}\text { Reject the } \\
\text { null thesis. } \\
\text { hypothesis. }\end{array}$ \\
\hline 27 & $\begin{array}{l}\text { The distribution of VAROODO27 is } \\
\text { normal with mean } 0,036 \text { and } \\
\text { standard deviation } 0,09 \text {. }\end{array}$ & $\begin{array}{l}\text { One-Sample } \\
\text { Kolmogoror } \\
\text { =Smirnov } \\
\text { Test }\end{array}$ & $.000_{1}$ & $\begin{array}{l}\text { Reject the } \\
\text { nulll thesis. } \\
\text { hypothesis. }\end{array}$ \\
\hline 28 & $\begin{array}{l}\text { The distribution of VAROO0028 is } \\
\text { normal with mean } 37,909 \text { and } \\
\text { standard deviation } 76,30 \text {. }\end{array}$ & $\begin{array}{l}\text { One-Sample } \\
\text { Kolmogorav } \\
\text {-Smirnov } \\
\text { Test }\end{array}$ &, $000_{1}$ & $\begin{array}{l}\text { Reject the } \\
\text { null thesis. } \\
\text { hypothesis. }\end{array}$ \\
\hline
\end{tabular}

Asymptotic significances are displayed. The significance level is, 05 . ${ }_{1}$ Lilliefors Corrected

Hypothesis Test Summary

\begin{tabular}{|c|c|c|c|c|}
\hline & Null Hypothesis & Test & Sig. & Decision \\
\hline 29 & $\begin{array}{l}\text { The distribution of VAROO029 is } \\
\text { normal with mean } 0,088 \text { and } \\
\text { standard deviation } 0,19 \text {. }\end{array}$ & $\begin{array}{l}\text { One-Sample } \\
\text { Kolmogorov } \\
\text {-Smirnor } \\
\text { Test }\end{array}$ &, $000_{1}$ & $\begin{array}{l}\text { Reject the } \\
\text { null } \\
\text { hypothes is. }\end{array}$ \\
\hline 30 & $\begin{array}{l}\text { The distribution of VARO0030 is } \\
\text { normal with mean } 86,120 \text { and } \\
\text { standard deviation } 174,17 \text {. }\end{array}$ & $\begin{array}{l}\text { One-Sample } \\
\text { Kolmogorov } \\
\text {-Smirnov } \\
\text { Test }\end{array}$ &, $000_{1}$ & $\begin{array}{l}\text { Reject the } \\
\text { null } \\
\text { hypothesis. }\end{array}$ \\
\hline
\end{tabular}

Asymptotic significances are displayed. The significance level is , 05 . ${ }_{1}$ Lilliefors Corrected 
Management and Production Engineering Review

\section{Appendix 4}

One sample T-test, difference between announced monetary values and actual energy.

One-Sample Test

\begin{tabular}{|c|c|c|c|c|c|c|}
\hline & \multicolumn{6}{|c|}{ Test Value $=0$} \\
\hline & \multirow{2}{*}{$\mathrm{t}$} & \multirow{2}{*}{ df } & \multirow{2}{*}{ Sig. (2-tailed) } & \multirow{2}{*}{ Mean Difference } & \multicolumn{2}{|c|}{ 95\% Confidence Interval of the Difference } \\
\hline & & & & & Lower & Upper \\
\hline Mon, ${ }^{*} \mathrm{~B}, €$ & 17,261 & 39 & 000 &, 57750 &, 5098 & ,6452 \\
\hline Mon, B, kcal & 17,997 & 39 & ,000 & 657,01600 & 583,1724 & 730,8596 \\
\hline Mon, ${ }^{*} \mathrm{~L}, €$ & 21,979 & 39 & ,000 & 1,51550 & 1,3760 & 1,6550 \\
\hline Mon, L, kcal & 20,190 & 39 & 000 & 723,67875 & 651,1798 & 796,1777 \\
\hline Mon, ${ }^{*} \mathrm{D}, €$ & 21,098 & 39 & ,000 & 1,09625 &, 9912 & 1,2013 \\
\hline Mon, D, kcal & 21,692 & 39 & ,000 & 857,43225 & 777,4789 & 937,3856 \\
\hline Tue, B, € & 15,514 & 39 & , 000 &, 67525 &, 5872 &, 7633 \\
\hline Tue, B, kcal & 17,497 & 39 & ,000 & 534,83175 & 473,0039 & 596,6596 \\
\hline Tue, L, $€$ & 20,666 & 39 & ,000 & 1,21725 & 1,0981 & 1,3364 \\
\hline Tue, L, kcal & 19,558 & 39 & ,000 & 714,49775 & 640,6054 & 788,3901 \\
\hline Tue, $\mathrm{D}, €$ & 17,799 & 39 & ,000 & 1,41225 & 1,2518 & 1,5727 \\
\hline Tue, D, kcal & 20,625 & 39 & , 000 & 797,86425 & 719,6172 & 876,1113 \\
\hline Wed, B, $€$ & 18,462 & 39 & ,000 &, 87350 &, 7778 &, 9692 \\
\hline Wed B, kcal & 19,107 & 39 & ,000 & 551,91375 & 493,4887 & 610,3388 \\
\hline Wed,L, $€$ & 16,543 & 39 & ,000 & 1,61325 & 1,4160 & 1,8105 \\
\hline Wed, L, kcal & 19,648 & 39 & ,000 & 1020,89000 & 915,7928 & 1125,9872 \\
\hline Wed, $\mathrm{D}, €$ & 21,466 & 39 & , 000 & 2,38910 & 2,1640 & 2,6142 \\
\hline Wed D, kcal & 21,570 & 39 & ,000 & 773,36350 & 700,8410 & 845,8860 \\
\hline Thu, B, € & 18,018 & 39 & ,000 &, 55425 &, 4920 &, 6165 \\
\hline Thu, B, kcal & 19,940 & 39 & ,000 & 512,72600 & 460,7163 & 564,7357 \\
\hline Thu, L, € & 17,942 & 39 & 000 &, 82100 &, 7284 &, 9136 \\
\hline Thu, L, kcal & 23,687 & 39 & ,000 & 966,90200 & 884,3347 & 1049,4693 \\
\hline Thu, D, $€$ & 22,951 & 39 & ,000 & 1,25650 & 1,1458 & 1,3672 \\
\hline Thu, D, kcal & 25,636 & 39 &, 000 & 648,44350 & 597,2804 & 699,6066 \\
\hline Fri, B, $€$ & 11,142 & 39 & ,000 &, 40350 & ,3302 &, 4768 \\
\hline Fri, B, kcal & 13,234 & 39 & ,000 & 438,17150 & 371,2018 & 505,1412 \\
\hline Fri, L, € & 19,585 & 39 & ,000 &, 96650 & ,8667 & 1,0663 \\
\hline Fri, L, kcal & 25,705 & 39 &, 000 & 812,39028 & 748,4633 & 876,3173 \\
\hline Fri, D, € & 22,184 & 39 & ,000 & 1,53500 & 1,3950 & 1,6750 \\
\hline Fri, D, kcal & 21,861 & 39 & ,000 & 1405,30650 & 1275,2831 & 1535,3299 \\
\hline
\end{tabular}

${ }^{*} \mathrm{~B}$ - breakfast, $\mathrm{L}$ - lunch, D - dinner.

\section{References}

[1] Budina N., Polackova H., Irwin T., Public-private partnerships in the new EU member states: managing fiscal risks, World Bank Publications, Vol. 114, 2007.

[2] Demirag I., Khadaroo I., Stapleton P., Stevenson C., The diffusion of risks in public private partnership contracts, Accounting, Auditing \& Accountability Journal, 25, 8, 1317-1339, 2012.
[3] Brown T.L., Potoski M., Van Slyke D.M., Managing public service contracts: aligning values, institutions, and markets, Public Administration Review, 66, 3, 323-331, 2006.

[4] Kaplan S., Framing contests: Strategy making under uncertainty, Organization Science, 19, 5, 729-752, 2008.

[5] Grönroos C., Towards service logic: the unique contribution of value co-creation, 2009. 
[6] Gansler J.S., Lucyshyn W., Evaluation of performance based logistics, retrieved November 28th, 2015 from

http://drum.lib.umd.edu/handle/1903/7044.

[7] Vargo S., Lusch R., Evolving to a new dominant logic for marketing, Journal of Marketing, 1-17, 2004.

[8] Almefelt L., Berglund F., Nilsson P., Malmqvist J., Requirements management in practice: findings from an empirical study in the automotive industry, Research in Engineering Design, 17, 3, 113-134, 2006.

[9] Ng I.C., Maull R., Yip N., Outcome-based contracts as a driver for systems thinking and servicedominant logic in service science: evidence from the defence industry, European Management Journal, $27,6,377-387,2009$

[10] Moulton S., Wise C., Shifting boundaries between the public and private sectors: implications from the economic crisis, Public Administration Review, 70, 3, 349-360, 2010.

[11] Kappeler A., Nemoz M., Public-private partnerships in Europe-before and during the recent financial crisis: economic and financial reports/European Investment Bank, 2010.

[12] Wang Y., A broken fantasy of public-private partnerships., Public Administration Review, 69, 4, 779-782, 2009.

[13] Puolustusministeriö b, retrieved November 28th 2015, from http://www.defmin.fi/files/1836/kumppanuus.pdf.

[14] Martin L.L., Performance-based contracting for human services: Lessons for public procurement, Journal of Public Procurement, 2, 1, 55-71, 2002.

[15] Doerr K., Lewis I., Eaton D.R., Measurement issues in performance-based logistics, 2005.

[16] Snyder C.M., Trost R.P., Trunkey R.D., Reducing government spending with privatization competitions: a study of the department of defense experience, Review of Economics and Statistics, 83, 1, 108-117, 2001.

[17] Gansler J.S., Lucyshyn W., Evaluation of performance based logistics: DTIC Document, 2006.

[18] Abednego M.P., Ogunlana S., Good project governance for proper risk allocation in public - private partnerships in Indonesia, International Journal of Project Management, 24, 7, 622-634, 2006.

[19] Randall W.S., Pohlen T., Hanna J., Evolving a theory of performance-based logistics using insights from service dominant logic, Journal of Business Logistics, 31, 2, 35-61, 2010.

[20] Berkowitz D., Gupta J., Simpson J., McWilliams J., Delayne L., Brown B., Cameron D., Sparks T., Performance based logistics, Center for the Management of Science and Technology, Huntsville, AL, 2003.

[21] Kleemann F.C., Essig M., A providers' perspective on supplier relationships in performance-based contracting, Journal of Purchasing and Supply Management, 19, 3, 185-198, 2013.

[22] Pine J.II, Gilmore J., The experience economy, Harvard Business Press, 2011.

[23] Gummesson E., Extending the service-dominant logic: from customer centricity to balanced centricity, Journal of the Academy of Marketing Science, 36, $1,15-17,2008$.

[24] Laki puolustusvoimista, Retrived November 28th, 2015, from http://www.finlex.fi/fi/laki/ajantasa/2007/20070551.

[25] Nakazawa T., Masuda H., Requirement-definitionconfirmation modeling approach for identifying uncertainties in product design processes, Paper presented at the ASME 2006 International Design Engineering Technical Conferences and Computers and Information in Engineering Conference, 2006.

[26] Oberg R., Probasco L., Ericsson M., Applying requirements management with use cases, Rational Software Corporation, 1998.

[27] Definition of PBC. Retrieved November 28th, 2015, from http://www.acquisition.gov/ far/01c/html/Subpart_37_6.html.

[28] Neely A., Exploring the financial consequences of the servitization of manufacturing, Operations Management Research, 1, 2, 103-118, 2008.

[29] Anteroinen J., Enhancing the development of military capabilities by a systems approach, Series 1: Publication No. 33, 2013.

[30] Valo A-L., Service operations in restaurant Sahara[Interview], January 3rd 2016.

[31] Gansler J., Lucyshyn W., Evaluation of performance based logistics, University of Maryland, 2006.

[32] Gansler J., Lucyshyn W., Vorhis C., Performance based services acquisition, University of Maryland, 2011. 